\title{
MARKET REACTION TO INTERNATIONAL INVESTMENT ANNOUNCEMENTS OF MALAYSIAN FIRMS: ILLUSION OR REALITY
}

\author{
Bany Ariffin \\ Faculty of Economic and Management \\ Putra Malaysia University, Malaysia. \\ D. Agus Harjito \\ Fakultas Ekonomi \\ Universitas Islam Indonesia Yogyakarta
}

\begin{abstract}
This research substantiates evidence on the efficiency of one of the fastest developing and largest emerging securities market (Kuala Lumpur Stock Exchange) in the Asia Pacific rim with respect to foreign investment announcements. Specifically, in this study we are interested in finding out whether or not: (1) foreign investment announcement is relevant information and market reacts toward it and (2) what forms of market reaction does this information produce. Our study focuses on international investment announcements made in 1990 through 2000 for firms listed on the main board of the Kuala Lumpur Stock Exchange (KLSE) of Malaysia. The result shows that the announcements of foreign investment produce a significant positive daily abnormal return surrounding the event period. This implies that foreign investment announcements do contain new relevant information and thus move the market. In addition, investors also generally react favorably to the international investment efforts of Malaysia firms listed at KLSE. This is evidenced by the significant positive reaction of the market to announcement of investments in foreign countries. The $t$-statistic for the fourteen days, prior and fourteen days after the announcement indicate non-significance abnormal returns. Since none of the abnormal return is statically significant for each one of the fourteen days before and after the event period, it seems that the market reflects this new information (foreign investment announcements) rather efficiently.
\end{abstract}

Keywords: market reaction, international investment announcement, relevant information.

\section{INTRODUCTION}

There are three fundamental questions concerning foreign investment announcements that this study try to address: (1) Does Malaysian stock market reacts toward foreign investment announcements made by Malaysian Multinationals Corporation (MNCs)? (2) If the announcements indeed contained relevant information and market reacted towards them, what forms of reaction does the market produce. (3) Is the Malaysian stock market efficient in reflecting information on foreign investment? In order to provide the answers, an event study has been conducted.

In previous studies that have employed Event Study methodology, it is hypothesized that firm specific news do have some valuation implications. Fama, Fisher, Jensen and Roll (1969), conduct an examination on firm specific news in the form of stock splits announcements. They discover 
that firms stock price reacted to the announcements and it adjusted according to the investor's reassessment of the future dividend after the stock splits. Numerous other studies also have examined the various types of firm-specific news and how the market reacted to them. Among them: Masulis (1980), Ball Brown and Finn (1977) on capital structure changes; Bradley, Desai and Kim (1988) on merger and acquisitions; Scholes (1972), on common stock's right issues; Chan, Gau and Wang (1995) on business relocation, etc. Using data for a sample of Malaysia firms, this paper adds to the existing literature by examining an additional type of firm specific news - foreign investment announcements.

On the local scene, Annuar \& Shamsher (1993), (1992) analyze the effects of stock splits and rights issues announcements on share prices in Malaysia. They find that these announcements create reactions in the market and the reactions eventually produce positive abnormal return to the investors. Thus, if foreign investment announcements are similar to those announcements studied by Annuar and Shamsher and they contain new information, the market price should change upon the release of such information. At the same time, if the market views the foreign investment announcements favorably, the stock prices of firms associated with these foreign activities should increase upon such announcements.

In developed capital market, studies that examine stock price reactions towards firm's foreign investment announcements have produced inconclusive results. Research done by Etebari (1993) examines the reaction of US stock priced towards 25 international joint ventures announcements between US firms and firms in Eastern and Central European countries. The results show that the stock price of the respective US firms reacted positively towards the announcement. Cructchley et al (1991) discover that both the Japanese and the US market produce positive response when there is an announcement of international cooperation between firms from these two countries. Lummer and McConnell (1990) provide evidence that foreign joint venture for US firms, on average are viewed by the investors as firm value enhancement. Hence they reacted positively, especially when the venture partner is a foreign firm as opposed to a foreign government. Doukas and Travlos (1988) find that US multinationals benefit the most when they announce acquisitions in less developed countries. They also find that multinationals not already operating in the target's country benefit from their acquisitions.

Despite numerous studies that documented positive stock market reactions towards foreign investment announcements, there are also studies that show the market reacted negatively towards such announcements. Markides and Ittner (1990) find that investor's reaction to US firm's foreign ventures with foreign firms in Canada and the UK is negative and only joint 
ventures with firms in Continental Europe create positive wealth effect. In Europe, Fatemi and Furtada (1988) find that in West Germany's foreign investments announcements are taken unfavorably by the market.

Theoretical arguments have been advanced over the years to explain the potential effects of foreign investments on firms involved and eventually to the shareholders. Some arguments suggest that significant benefit should accrue to the shareholders of firms involved in while others suggest that the effects may be negative. In either cases the effects shall transpire on the specific firm's stock prices

In terms of potential positive effects of foreign investment, Shapiro (1996) suggests that the benefits may arise based on the fact that the economies of different countries in which the multinationals operate are less than perfectly correlated. When the countries are less than perfectly correlated, this will help firms in reducing the variability of their earnings provided they have their investments in multiple countries. Also by expanding internationally according to Shapiro, firms will be able to increase their market shares. The benefits of serving a bigger market to firms are, they may then able to achieve the stage of economies of scale faster. In edition foreign investments in the form of joint ventures may allow the firm to enter a market to which it would not otherwise have access. This is particular true in those instances in which foreign government prohibits $100 \%$ foreign ownership of subsidiaries. To the extent that foreign investments could improve firm's profitability and shareholder value, higher stock returns should be associated with any foreign investments announcements.

In addition to the potential gains from foreign investments, there are a number of arguments supporting negative effects of such firm's activities. Jensen (1986) "free cash flow" theory suggests that managers sometimes may be inclined to over-invest in some unprofitable projects due to the motivation of expanding firm's empire and obtaining prestige. These unprofitable foreign ventures ultimately will diminish the value of the parent firms. Madura (2000) argues that when firms expand beyond their national borders, they have to contend with new national and corporate culture. These culture barriers can represent formidable challenges and they can offset the gain a firm might obtain from international expansion. In addition, country risk may also reduce the potential benefits of foreign investments. Changes in economic and political factors in the host country (unpredictable policy changes brought on by frequent changes in the government's structure, blocked funds, or expropriation) are examples of country risk, which may have adverse effects on firm's cash flows. Lastly, foreign investment is further complicated by exposure to exchange rates and potential conflicts with the foreign joint venture partner, which can overwhelm the benefits of the joint venture. 
In general, although studies on stock price reaction to foreign investment announcements are abundant, unfortunately there are none that gave focused on the stock market located in the developing market. In order to substantiate evidence on the efficiency of developing stock market with respect to foreign investment announcements, this study focuses on Kuala Lumpur Stock Exchange (KLSE). Annuar and Shamsher (1992) pointed out that KLSE is one of the fastest developing and the largest emerging securities market in the Asia Pacific rim. Specifically as mentioned earlier, in this study we are interested in finding out whether or not: foreign investment announcement is relevant information and stock price reacted to it. And if foreign investment announcement is relevant information and stock price reacted to it, does it creates positive or negative reactions.

\section{FOREIGN INVESTMENTS BY MALAYSIAN COMPANIES}

According to Madura (2000) foreign investments can be in many forms. Among them are; acquisitions of existing companies in foreign countries, a joint venture with companies in foreign countries and opening up a company's subsidiary in foreign countries. Companies that conduct any these forms of investments in foreign countries are known as (MNCs) Multinational Companies (Dunning 1993). Bala (1999) conduct a survey of foreign investments conducted by firms listed at KLSE in order to identify MNCs originating from Malaysia. From the 436 listed firms (as at October 1997), he discovers that 207 firms are actively involve in foreign investment activities and they can be considered as MNCs.

In that survey, it was also discovered that seventeen companies have more than 20 ongoing foreign investment projects in various countries. Top of the list is Sime Darby with 110 ongoing foreign investment activities spanning in 19 countries. Second is Amsteel with 70 ongoing foreign investment activities and this is followed by MBF holding with 60 (Bala 1999).

The geographical spread of Malaysia's MNCs investment activities are also wide. In total, the top MNCs have ongoing foreign investments in 63 countries around the world. The spread of these investments according to region is shown in table 1. It is interesting to note that in comparison to other regions, the North East Asia and the Asean regions, receive the most of Malaysia's MNCs foreign investments. Perhaps, this phenomena is due to the inferiority of technology and "know-how" of the Malaysia's MNCs. This inferiority factor discourage them from penetrating the western countries and compete with the much sophisticated firms in those market. Many MNCs from developing countries are also facing similar situation (Lall 1986). In the case of Malaysian MNCs, since there is high probability of winning the competition against local firms in developing countries like East 
Asia and the Asean regions, thus this may explain why the two regions have been the focused of Malaysia's foreign investments.

Although, Malaysian MNCs are at a disadvantage when competing against firms in developed countries, there are still some foreign investment made by the MNCs in those countries (see table 1). Bala (1998) pointed out that majority of the investment of Malaysian MNCs in countries such as United States, Europe and Australia are in the formed of fixed assets with less technology requirements. For example, investments in hotels chain, restaurants, marketing chains, etc. Since the technology requirements are less for such investments, this give an opportunity for Malaysian MNCs to compete more competitively with local firms originated from those countries.

Table 1: Spread of foreign investments according to region

\begin{tabular}{|l|c|}
\hline \multicolumn{1}{|c|}{ Region } & Number of foreign investments \\
\hline ASEAN & 29 \\
\hline Singapore & 15 \\
Indonesia & 9 \\
Thailand & 9 \\
\hline Philippines & \\
\hline Europe & 15 \\
\hline United Kingdom & 8 \\
Netherlands & 7 \\
Germany & 6 \\
\hline France & \\
\hline East Asia & 22 \\
\hline China & 24 \\
Hong Kong & 4 \\
Taiwan & 3 \\
Japan & 2 \\
\hline Korea & \\
\hline North America & 17 \\
\hline USA & 5 \\
\hline Canada & \\
\hline South Pasific & 20 \\
\hline Australia & 1 \\
New Zealand & 6 \\
\hline Papua New Guinea & \\
\hline
\end{tabular}

Malaysian MNC's may also be investing in developed countries in order to diversify their total investments. Different from investment in developed countries, foreign investments in developing countries are perceived 
to have higher business risk. For example a project undertaken in developing countries, it is said to be in a more volatile operating environment than a project in larger developed economy. The volatility is due potentially greater infrastructure risk, customer risk, banking system/payment risk, labor risk and political risk (Madura 2000) This move to diversify investments into developing market as well as developed market perhaps was partly an afford by some of the MNCs to reduce risk.

There are also others initial surveys on Malaysian MNC in the past, and one of the earliest was by Heenan \& Keegan (1979). The objective of their survey was to identify MNCs originating from the third world. During that period they found only one company that fitted their definition of MNC and it was the Sime Darby Holdings. In more recent study, Annuar Adnan, Supian Ali \& Anuwar Ali (1996), considered companies like Technology Resources Industries (TRI), Sapura Telecommunications Berhad, Telekom Malaysia and Petronas as Malaysia's major MNCs. UNCTAD (1999), in their study to identify Third World transnationals listed Petronas and Sime Darby in their top 50 transnationals from developing countries based on foreign assets.

\section{RESEARCH HYPOTHESIS}

By looking at the past and more recent surveys, it seems that the number of MNCs that are based in Malaysia have increased significantly. One of the criteria that a firm must fulfill in order to be classified as MNCs, is that the firm must be involved in investment activity outside domestic market in a significant way. Hence, more MNCs means more foreign investments activities. Bala (1999) had pointed out that half of the firms that are listed on the KLSE are MNCs. Because these firms are highly associated with foreign investment activities and their numbers are significant, we hypothesize that foreign investment news or announcement are not scarce and it is relevant to Malaysia's stock market. In short, the market should react to any announcement on foreign investment by any Malaysian MNCs.

A prudent firm will not be involved in a foreign investment unless the investment is expected to generate positive return to the firm and the shareholder (David and Qian 1997). The same can be said about firms in Malaysia. Generally firms will engage in foreign investment activities only if they are sure that the investments will bring positive returns. Therefore if the number of foreign investment activities are increasing as pointed out earlier, this is likely imply to that Malaysian MNCs have encountered success in their past foreign investments activities and with that they are confidence to pursue more foreign activities. A successful foreign investment project increases firm's profit and also creates wealth for the shareholders 
of the firm. Hence in lieu to the increasing number of successful foreign activities and how that can impact shareholder wealth, we hypothesize that the market shall react positively to news or announcement of foreign investments.

\section{DATA AND METHODOLOGY}

In order to assess the overall valuation effects of foreign investment announcements, we have compiled samples of foreign investment announcements involving Malaysia firms listed on the KLSE main board over the period from 1990 through 2000. According to Bala (1998), the activity of foreign investments by Malaysia firms did not actually grow substantially prior to 1990 . However, such activities increased significantly from 1990 onwards due to the financing incentives given by the local government to the local forms. Hence choosing 1990 as the starting period of our study, we believe is appropriate. The announcements are gathered from various reliable sources (firm's annual report, Investors Digest, KLSE daily dairy and local newspaper's cuttings). To be included in the final sample, each of the foreign investment announcements has to meet the following criteria:

a. The date of the announcement could be identified

b. No major confounding announcements (i.e. earnings, dividends, share repurchase) are made within $+/$ - 14 days of the announcement.

c. Multiple foreign investment announcements by the same company are treated as separate observation if the subsequent announcement occurs two or more weeks after previous announcements.

d. The stock prices of the firms that make the announcements are available.

This screening procedure produced a sample of 60 clean foreign investment announcements (see table 2). The overall sample announcements were also divided according to the development of the target country (where the investment is suppose to be made). In general whether a target country is classified as developed or developing, it all depend on the overall infrastructure development of the country. In this study we utilized the classification of the International Monetary Fund (IMF) to classified target country into developed or developing country. Overall, we found 30 foreign announcements were mean for developed countries and the remaining 30 for developing countries.

Standard event-study methodology is used to assess the impact of foreign investment announcements on stock returns. The most crucial assumption of the methodology is that capital market is efficient (in the semistrong form). This implies that the price of any security incorporates all cur- 
rently available public information and adjusts to the public release of new information instantaneously.

Table 2: Foreign investment announcements and target country

\begin{tabular}{|l|c|l|c|}
\hline \multicolumn{2}{|c|}{ Developed Market } & \multicolumn{2}{c|}{ Developing Market } \\
\hline \multicolumn{1}{|c|}{ Country } & No. of Announcement & \multicolumn{1}{c|}{ Country } & No. of Announcement \\
\hline Switzerland & 1 & Thailand & 3 \\
\hline Germany & 1 & China & 4 \\
\hline Singapore & 2 & Vietnam & 4 \\
\hline Canada & 1 & Philippine & 3 \\
\hline USA & 7 & Indonesia & 4 \\
\hline Sweden & 1 & Cambodia & 3 \\
\hline Holland & 1 & India & 2 \\
\hline New Zealand & 1 & Chile & 1 \\
\hline Japan & 3 & South. Africa & 3 \\
\hline France & 1 & Albania & 1 \\
\hline UK & 2 & Ghana & 1 \\
\hline Australia & 7 & Uzbekistan & 1 \\
\hline Finland & 1 & & \\
\hline South Korea & 1 & & 30 \\
\hline Total & 30 & & \\
\hline
\end{tabular}

The commonly used event-study methodology is based on a market model describe by Fama (1976). The model helps predict a firm's normal or expected return given the market return and the firm historical relationship to the market. Thus, for each firm the following model is estimated:

$E R_{i t}=a_{i}+b_{i} R_{m t}+e_{i t}$ where :

$E R_{\text {it }} \quad=$ Expected return on the security of firm I at time $t$;

$R_{m t} \quad=$ Return on the market portfolio at time $t$, peroxide by the return on the Kuala Lumpur Composite Index $(\mathrm{KLCl})$

$a_{i}$ and $b_{i}=$ parameters of the relationship between the return on the individual security and that of the market

$e_{i t}$ $=$ residual of the relationship at time $t$

The parameter alpha $\left(a_{i}\right)$ and beta $\left(b_{i}\right)$ are estimated for each security $i$ over the period of three years prior to the announcement of the foreign investments. These parameters are then used to calculate the expected returns over the test period. The difference between the actual re- 
turns $\left(R_{i t}\right)$ and the expected returns for each day and for each firm are called abnormal returns $\left(A R_{i t}\right)$ and are computed as follows:

$$
A R_{i t}=R_{i t}-\left(\hat{a}+\hat{b} R_{m t}\right)
$$

where $a$ and $b$ are the estimated parameters $\mathrm{a}$ and $\mathrm{b}$ of firm $\mathrm{i}$. The abnormal returns (AR) of each company stock are determined over the event period of 31 days $(t=-14$ to $t=+14)$. If announcements of foreign investment have no impact on stock prices, then on average, one should expect abnormal returns to be zero. Also in this study, we aggregate all of firm's abnormal return observations in order to draw overall inferences for the event of interest. We look at the average effects of the announcement rather than examining each firm separately, because other events are occurring and averaging across all firms should minimize the effect of these other events (Haugen 2001). For sample of $N$ firms, a daily average abnormal return (AR) for each day $t$ is obtains:

$$
A R_{t}=1 / N \sum_{j=1}^{N} A R_{j t}
$$

In this study we define event period as day $t=0$ and day $t=+1$. We adopt this technique in order to cater for late announcement release (after market close) during announcement day (Yong et al, 2002). By doing this, it allows the stock price to fully absorbed the information on the announcement day. In order to determine if there is an impact of foreign investment announcements on stock returns, thus producing a significant average daily abnormal return, the student's t-test statistic on any day $t$ in the event window for all $n$ stocks is constructed.

$$
t-\text { statistic }=\frac{\overline{A R}}{\sqrt{\operatorname{Var}\left(A R_{t}\right)}}
$$

One would expect if the foreign investment announcements do not have an impact on common stock return listed on KLSE, the daily average abnormal returns for all the sample stocks surrounding the event period should not be statically significantly different from zero.

\section{EMPIRICAL RESULTS}

Table 3 shows the average daily abnormal returns, the t-value for the total sample of 60 foreign investment announcements for the period 14 to +14 days relative to the announcement day $(t=0$ and $t=+1)$. As shown in table 3 , the announcements of foreign investment (on day $=0$ ) produce a significant positive daily abnormal return of 0.01142 (t-statistic of 
2.14). This result implies that foreign investment announcements do contain new relevant information and thus move the market. Also, investors generally react favorably to the international investment efforts of Malaysia firms listed at KLSE. This is evidenced by the significant positive reaction of the market to announcement of investments in foreign countries.

Table 3: Abnormal and Cumulative Abnormal Returns (CAR) around foreign investment announcements

\begin{tabular}{|c|c|c|c|}
\hline Day & Abnormal Return & $\begin{array}{c}\text { T-value for } \\
\text { (Abnormal Return) }\end{array}$ & CAR \\
\hline-14 & 0.002820638 & 0.528541132 & \\
-13 & -0.007836517 & -1.468434351 & -0.00502 \\
-12 & 0.001302147 & 0.244001007 & -0.00371 \\
-11 & 0.002326157 & 0.435883599 & -0.00139 \\
-10 & 0.001536834 & 0.287977415 & 0.000149 \\
-9 & -0.001105914 & -0.207230016 & -0.00096 \\
-8 & -0.006122354 & -1.147228381 & -0.00708 \\
-7 & 0.005131175 & 0.961497733 & -0.00195 \\
-6 & -0.00515508 & -0.965977277 & -0.0071 \\
-5 & 0.005824494 & 1.091414396 & -0.00128 \\
-4 & 0.003756104 & 0.703832194 & 0.002478 \\
-3 & -0.009405226 & -1.762384659 & -0.00693 \\
-2 & -0.000445184 & -0.083420107 & -0.00737 \\
-1 & 0.000505081 & 0.094643899 & -0.00687 \\
0 & 0.011429699 & $2.141737611^{* *}$ & 0.004562 \\
1 & 0.003452757 & 0.64698991 & 0.008015 \\
2 & 0.006209779 & 1.163610442 & 0.014225 \\
3 & -0.002005474 & -0.37579291 & 0.012219 \\
4 & -0.006864321 & -1.286260847 & 0.005355 \\
5 & 0.002239134 & 0.419576811 & 0.007594 \\
6 & 0.006859717 & 1.285398217 & 0.014454 \\
7 & -0.002605698 & -0.488264971 & 0.011848 \\
8 & -0.005390301 & -1.010053834 & 0.006458 \\
9 & 0.005982399 & 1.121003234 & 0.01244 \\
10 & -0.006132323 & -1.149096534 & 0.006308 \\
11 & -0.009840988 & -1.84403926 & -0.00353 \\
12 & 0.0006704 & 0.125621945 & -0.00286 \\
13 & 0.003451891 & 0.646827556 & 0.000589 \\
14 & 0.002087385 & 0.391141618 & 0.002676 \\
\hline
\end{tabular}

Note: *significant at $5 \%$

$$
{ }^{*} \text { significant at } 1 \%
$$


The t-statistic for the fourteen days prior and fourteen days after the announcement indicate non-significance abnormal returns. Since none of the abnormal return is significant for each one of the fifteen days before and after the event period, it seems that the market reflects this new information (foreign investment announcements) rather efficiently.

Overall, the finding shows that foreign investments activities engage by Malaysian MNCs, are value-increasing activities for Shareholders of Malaysian firms. Results are consistent with the findings of Etebari (1993), Cructchley et al (1991) and Lummer and McConnell (1990) which reveal that international expansion benefits shareholders of firms that engage in such activities.

\section{CONCLUSION AND IMPLICATIONS}

Globalization has become a buzz word for the business sector in the developed market since the early 1970's (Shapiro 1996). At the heart of the globalization process are the multinational corporations (MNCs). These firms are known to carry out cross border investments (foreign investments) in a significant manner. Because the growth in foreign investments have been very rapid, evaluation of profitability performance of such investments was necessary to justify such activity. The results of the evaluations, from time to time have produced mixed results. Hence there are foreign investments that generate positive returns and there are also those investments that failed to do so.

One of the many techniques employed by the researchers to evaluate the foreign investments performance, is to see firm's stock price reaction towards foreign announcement. This technique is also commonly known as event-study methodology. Accordingly, this technique assumes that the capital markets are efficient, which implies that the price of any security incorporates all currently available information and adjusts to the public release of new information instantaneously. For example, if the public perceives that the foreign investments would generate positive returns for the respective firm, they will react on the announcement day, by buying the firm's security. This reaction causes the security to yield positive return on the announcement day. On the other hand if the public perceive that the foreign investments would generate negative returns for the respective firm, they will react on the announcement day, by disposing the firm's security. This reaction causes the security to yield negative returns on the announcement day.

Similar to other techniques that have been used to evaluate foreign investment performance, studies on stock price reaction towards foreign investment announcements in developed market have produced in- 
conclusive results. Etabari (1993); Cructchley et al (1991); Lummer and McConnell (1990); Doukas and Travlos (1988) provide evidence that market reacted positively to foreign investment announcements. In contrast, Markides and Ittner (1990); Fatemi and Furtado (1988); have documented that the market reacted significantly negative to similar announcements.

Research of such kind is still uncommon for developing market like Malaysia. Therefore in order to substantiates evidence on the efficiency of developing stock market with respect to foreign investment announcements, this study focuses on Kuala Lumpur Stock Exchange (KLSE). The study focuses on foreign investment announcements primarily made from 1990 to 2000 for stock listed on the main board of the KLSE.

The objectives of this study are to find out whether or not foreign investment announcement is relevant information and stock price reacted to it. Secondly, what kind of stock price reactions does this announcement produced and finally does public information in the form of foreign investment announcement is efficiently reflected in the stock price.

In this study, standard event-study methodology is used to assess the impact of foreign investment announcements on stock returns. Also we employ the standard market model in calculating the excess or abnormal return. We define the event period as day $t=0$ and day $t=+1$. We adopt this technique in order to cater for late announcement release during announcement day (after market close). By doing this, it allows the stock price to fully absorbed the information following the announcement day (Yong et.al 2002).

We hypothesize if the foreign investment announcements do not have an impact on common stock return listed on KLSE, the daily average abnormal returns for all the sample stocks should not be significantly different from zero surrounding the event period. However, if the information is significant and the common stock reacted, we expect the daily average abnormal returns for all the sample stocks should be significantly different from zero surrounding the event period. In addition, if the market reflect this announcement efficiently (that is immediately and accurately) in the stock price, the abnormal return for the periods before and after the announcement are not expected to be significantly different from zero for each of the day.

The result shows that the abnormal returns of the securities are significantly positive surrounding the event period. This result implies that unexpected foreign investment announcements do contain new relevant information and thus move the market. Also, investors generally react favorably to the international investment efforts of Malaysia firms listed at KLSE. At the same time, in terms of the efficiency of the market in reflecting this information, we make the conclusion that the market is efficient. This is 
because none of the abnormal return is significant for each one of the fourteen days before and after the event period.

Overall, the market response positively to Malaysia based MNCs cross border investment announcements. We try to find possible explanation for this phenomenon. Among many explanations that we can relate to, the explanation provided by David and Qian (1997) seems most reasonable. They argue that firms from small country like Singapore benefited from their foreign investment activities because such activities assist them in reducing their operation cost (thus producing significant abnormal return around the event period). According to them Singapore is a small open economy. As the economy matures, living standards increased dramatically and eventually so did the production costs. In order to sustain competitiveness, the only solutions for these firms are to operate in countries where the costs of production are still low. Since foreign investments into foreign countries could lower the operation cost, effort was made by those firms to intensify cross border investments (FDI). Similar scenario could be observed for some of the industries in Malaysia. These industries are also slowly approaching the maturity stage (Bala 1999). Strategy to invest and operate in countries where the operation cost are still minimal could help some of the affected Malaysia firms in sustaining their competitiveness. Hence announcement to go abroad is perceived as positive sign by the market.

\section{REFERENCES}

Annuar Adnan, Supian Ali \& Anuwar Ali (1996). Globalization challenges and Competitiveness: The role of the state and private sector in Malaysia. Managerial Finance. 22(5/6), 59-69

Annuar, M.N., and M. Shamsher (1992) Do interim earnings announcements convey news to Investors? The case of the Kuala Lumpur Stock Exchange. Akautan Nasional, 3: 29-35

Annuar, M.N., and M. Shamsher (1993) Share price reaction to bonus issues. Capital Market Review, Vol 1(2): 67-81

Ball, R., Brown, P., and Finn, F.J. (1977) Share capitalization changes, information and Australian equity market. Australian Journal of Management (2) 105-117

Bala Ramasamy (1999) Third World Multinastionals: The case of Malaysia. Jurnal Analisis, 6: 123-137

Bala Ramasamy (1998) Malaysia's investment development path. Malaysian Management Review, 1-7 
Bradley, M., A. Desai., and E.H. Kim (1988) Synergistic gains from corporate acquisitions and their divisions between the shareholders of target and acquiring firm. Journal of Financial Economics, 21: 3-40

Chan, S.,G. Gau., and K. Wang ( 1995) Stock market reaction to capital investment decisions. Journal of Financial Quantitative Analysis. 30: $81-100$

Crutchley, C.,Guo, and E.,Hansen, R.S., ( 1991) Stockholder benefits from Japanese- US joint ventures. Financial Management, 20: 22-30

Dunning, J. H. (1993). Multinational Enterprises and the Global Economy. UK: Addison Wesly.

Doukas, J. and Travlos, G. (1988) The effect of corporate multinationalism on shareholders wealth: evidence from international acquisitions. Journal of Finance, 43 (5): 1161-75

Etabari, A., (1993). Market impact of announcement of joint ventures between US firms and eastern and central European countries: Early evidence. Global Finance, 4: 103-123

Fama, E. F. (1976). Foundation of Finance. New York: Basic Books.

Fama, E.F., L. Fisher., M.C. Jensen., and R. Roll ( 1969) The adjustment of stock prices to new information. International Economic Review 63(1) $1-21$

Fatemi, A., and Furtado, E.P. (1988) An empirical investigation of the wealth effect of foreign acquisations. Recent Development in International Banking and Finance (Vol. 2) 363 -379.

Heenan, D. A. \& Keegan, W. J. (1979). The rise of third world Multinationals. Harvard Business Review, 57 (1).

Haugen, R.J (2001). Modern Investment Theory. (5th edition). Prentice Hall Publishing, Upper Saddle River, New Jersey, USA: 592-593

Jensen, M., (1986) Agency cost of free cash flow, corporate finance and takeovers. American Economic Review, 76: 323-329

David K.D., and Qian, S. (1997) Information content of FDI announcement: Evidence from an emerging market. International Review of Financial Analysis. Vol 6, No 1, p. 63-76

Lall, R. (1986) Developing countries as exporters of technology. A preliminary analysis. In H. Giersch (Ed), International Development and Resource Transfer. Tubingen: Mohr. 
Lummer, S.L.,and McConnell, J.J., ( 1990) Stock valuation effects of international joint ventures. In:Rhee, S.G., Chang, R.P. ( Eds), PacificBasin Capital Market Research. Elsevier Science, New York, 531546.

Madura, J (2000) International Financial Management (6 $6^{\text {th }}$ edition). South Western College Publishing, New York, USA.: 177-180.

Markides, C. and Ittner, D. (1990) The valuation consequences of international acquisitions. Cyprus Journal of Economics, 3 (1): 1-18.

Masulis, R. (1980) The effect of capital structure changes on security prices. Journal of Financial Economics. 8: 139-178.

Shapiro, A.C. (1996) Multinational Financial Management, Prentice Hall Publishing, Upper Saddle River, New Jersey, USA: 630-635.

Scholes, M. S. (1972) The market for securities: substitution vs. price pressure and the effect of information on share prices. Journal of Business $45,179-211$

UNCTAD (1999). World Investment Report 1999: FDI and the challenge of development. New York: United Nations

Yong, O.; Sapian, R Z.Z., Hamid, M.a, Yaacob, M.H (2002). Dividend changes and stock prices revisited: The Malaysian experience. Occasional working paper, Department, Faculty of Business Management, Universiti Kebangsaan Malaysia, Malaysia. 


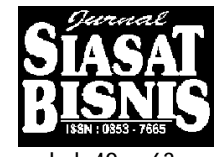

hal: $49-63$

1) Bany Ariffin

Department of Accounting and Finance, Faculty of Economic and Management

Putra Malaysia University, Serdang.

Selangor 43300, Malaysia

bany@Putra.upm.edu.my

2) D. Agus Harjito

Department of Management, Faculty of Economic

Islamic University of Indonesia.

Yogyakarta, 55283 Indonesia

agus h@fe.uii.ac.id or harjitok@yahoo.com

Hal: Pengirriman naskah artikel

Kepada Yth.

Pimpinan Redaksi Jurnal Siasat Bisnis

Fakultas Ekonomi UII

di Yogyakarta. 
Assalamu'alaikum.wr.wb.

Bersama surat ini kami kirimkan sebuah naskah artikel hasil penelitian berjudul "Market Reaction to International Investment Announcements of Malaysian Firms: Illusion or Reality". Kami mohon artikel ini dapat dimuat/diterbitkan oleh Jurnal Siasat Bisnis. Bersama ini pula, kami sertakan disket artikel tersebut.

Demikian, atas perhatian dan kerjasamanya disampaikan terima kasih.

Wassalamu'laikum.wr.wb.

10 Nopember 2003.

Yogyakarta,

lis,

A.n. Penu-

D. Agus

Harjito 